\title{
A Comparison of Different Approaches for Assessing Energy Outputs of Combined Heat and Power Geothermal Plants
}

\author{
Daniele Fiaschi $^{1}{ }^{\circledR}$, Giampaolo Manfrida ${ }^{1}$, Barbara Mendecka ${ }^{2, *}$, Lorenzo Tosti $^{3}\left(\right.$ and Maria Laura Parisi $^{3,4}$ \\ 1 Department of Industrial Engineering (DIEF), University of Florence, 50135 Florence, Italy; \\ daniele.fiaschi@unifi.it (D.F.); giampaolo.manfrida@unifi.it (G.M.) \\ 2 Department of Economics, Engineering, Society and Business Organization (DEIM), University of Tuscia, \\ 01100 Viterbo, Italy \\ 3 Center for Colloid and Surface Science (CSGI), University of Florence, 50135 Florence, Italy; \\ tosti@csgi.unifi.it (L.T.); marialaura.parisi@unisi.it (M.L.P.) \\ 4 Department of Biotechnology, Chemistry and Pharmacy (DBCF), University of Siena, 53100 Siena, Italy \\ * Correspondence: barbara.mendecka@unitus.it
}

check for

updates

Citation: Fiaschi, D.; Manfrida, G.;

Mendecka, B.; Tosti, L.; Parisi, M.L. A

Comparison of Different Approaches

for Assessing Energy Outputs of

Combined Heat and Power

Geothermal Plants. Sustainability

2021, 13, 4527. https://doi.org/

$10.3390 /$ su13084527

Academic Editors: Alessandro Franco, Lorenzo Talluri and Fausto Batini

Received: 16 March 2021

Accepted: 18 April 2021

Published: 19 April 2021

Publisher's Note: MDPI stays neutral with regard to jurisdictional claims in published maps and institutional affiliations.

Copyright: (c) 2021 by the authors. Licensee MDPI, Basel, Switzerland. This article is an open access article distributed under the terms and conditions of the Creative Commons Attribution (CC BY) license (https:/ / creativecommons.org/licenses/by/ $4.0 /)$.

\begin{abstract}
In this paper, we assess using two alternative allocation schemes, namely exergy and primary energy saving (PES) to compare products generated in different combined heat and power $(\mathrm{CHP})$ geothermal systems. In particular, the adequacy and feasibility of the schemes recommended for allocation are demonstrated by their application to three relevant and significantly different case studies of geothermal CHPs, i.e., (1) Chiusdino in Italy, (2) Altheim in Austria, and (3) Hellisheidi in Iceland. The results showed that, given the generally low temperature level of the cogenerated heat (80-100 ${ }^{\circ} \mathrm{C}$, usually exploited in district heating), the use of exergy allocation largely marginalizes the importance of the heat byproduct, thus, becoming almost equivalent to electricity for the Chiusdino and Hellisheidi power plants. Therefore, the PES scheme is found to be the more appropriate allocation scheme. Additionally, the exergy scheme is mandatory for allocating power plants' environmental impacts at a component level in CHP systems. The main drawback of the PES scheme is its country dependency due to the different fuels used, but reasonable and representative values can be achieved based on average EU heat and power generation efficiencies.
\end{abstract}

Keywords: allocation; combined heat and power (CHP); geothermal energy; exergy; life cycle assessment (LCA); primary energy savings (PESs)

\section{Introduction}

The European Union (EU) has initiated an ambitious energy and climate policy framework called "Clean Energy for all Europeans". This framework sets specific targets to be met by 2030 in order to reduce greenhouse gas (GHG) emissions, increase the share of renewable energy in the EU's energy mix, and increase energy efficiency throughout the entire energy value chain $[1,2]$. In this context, power generation has been identified as one of the sectors with the highest potential to fully decarbonize. Energy production from renewable sources should play a key role in achieving such an ambitious objective. Among renewables, geothermal energy is currently attracting attention for its potential as a reliable, low-emitting source of heat and power that provides continuous base-load energy production in contrast to the highly fluctuating production profiles of, for example, wind and solar energy. Furthermore, geothermal energy is an excellent source of heat for district heating purposes. Therefore, environmental sustainability of power plants and geothermal exploitation settlements are receiving increased attention. A life cycle assessment (LCA) is one of the acknowledged methodologies for assessing the sustainability of energy systems [3]. The application of a LCA to geothermal power plants has received increased interest and importance in the last decade $[4,5]$. The results of a LCA can vary significantly depending on the methodological choices made, i.e., the use of 
different characterization models to assess a certain impact category or the use of specific allocation methods. This is especially important in the context of energy systems, where a multigeneration system is considered to be one of the ways of enhancing the utilization of primary resources and reducing wasted energy. Detailed methodological guidelines that facilitate a LCA specifically for deep geothermal installations have been developed within the EU GEOENVI project [6]. The function of a geothermal system is to produce electricity or heat. In a multigeneration energy system, such as a combined heat and power (CHP) plant, these products can be generated simultaneously. Heat from a CHP plant can be used for hot water, space heating directly or by district heating, industrial heating, and also for cooling by using it to drive absorption chillers [7].

Generally, much of the literature refers to LCA results for electricity output, especially in deep geothermal applications where it represents the main product, but also when analyzing CHP stations. This has led to marginalization of the cogenerated heat, which is often a relevant and very useful product for district heating $(\mathrm{DH})$ of local neighborhood communities.

According to the ISO 14040 standards for LCA [8], when systems have more than one product, either partitioning or allocation of the system impacts is inadvisable while "expanding the product system to include the additional functions related to the coproducts" is recommended. However, in practice, the system expansion approach is often based on inaccurate data regarding the alternative production or exported functions [9].

As far as the literature is concerned, different methods of environmental burden allocation for heat and power production have been suggested and assessed. For example, Tereshchenko et al. [10] compared seven methods for emissions allocation from combined cycle power plants (CCPP) and demonstrated how the allocation factors could vary for the same case study. More specifically, the fuel allocation for heat with the alternative generation method was $38.3 \%$, while it was equal to $22.3 \%$ with the power bonus method.

Karlsdottir et al. [11] discussed the possibility of using different methods to calculate partitioning and allocation factors, to be later applied for evaluating the products generated in the geothermal CHP plant. Specifically, they applied the following approaches: no allocation, energy, exergy, economic, and alternative generation method, to divide the primary energy factor (PEF) and greenhouse gas (GHG) emissions between power and heat produced at the Hellisheidi geothermal power plant.

The results of the abovementioned studies confirm the need for a reliable allocation scheme to distribute the life cycle inventory (LCI) data and environmental burdens between the different coproducts for CHP systems, especially in the context of EU energy and climate policy. Concerning geothermal systems, the GEOENVI methodological guidelines $[6,12]$ recommend using two approaches to solve a multifunctionality problem, depending on the share between coproducts. If the contribution of one of the products (electricity or heat) exceeds $75 \%$, a system expansion with a substitution model for the coproducts is proposed, while if the share between the coproducts is lower than $75 \%$, the system allocation scheme should be based on the exergy method. Moreover, for systems producing large amounts of heat, a comparison of the allocation schemes using either exergy or primary energy saving (PES) methodology can be applied [6]. From a thermodynamic point of view, the exergy allocation method is considered to be a fair method for dividing the benefits of the CHP production between electricity and heat; moreover, it is widely used in LCA studies related to the geothermal sector $[13,14]$. However, geothermal CHP plants in various locations around the world are either heat or electricity production oriented, depending on the local energy demand and climatic conditions; the choice of the allocation scheme significantly affects the impacts of the electricity and heat outputs. Such an issue can be addressed using a PES approach which is a specific measure used for evaluating energy systems producing both electricity and heat that compares locally generated CHP coproducts to those from a conventional system separately producing separately the same two amounts of electricity and heat. This indicator provides, similarly to exergy, a common basis for various products generated in energy systems, and therefore can be used to formulate the allocation factor. 
In this study, we present and compare two allocation procedures based on exergy and PES methods for evaluating the useful products of geothermal CHP plants. The main novelty of this study is the assessment of how the PES allocation method may suitably valorize heat production in geothermal CHP systems with respect to the traditional exergy allocation method. Moreover, in this study, we extend the abovementioned methods to address the allocation problem for relevant and representative case studies of geothermal CHP plants, i.e., Chiusdino (Italy), Altheim (Austria), and Hellisheidi (Iceland), and we investigate how the chosen allocation scheme would affect the impact of heat- and electricity-oriented CHP plants of different technical and geographical scales.

For the analysis, we chose allocation factors based only on the physical properties of the products. Economically based allocation factors are excluded from this study since the prices that are the basis of this method are strongly variable and easily influenced by decision and policy makers.

An energy allocation approach is considered to be questionable from a thermodynamic point of view, especially for CHP systems where it does not reflect the difference in terms of energy quality and usefulness among the two functions provided by the system. However, it is used in this study to provide a general comparative framework.

This paper is divided into the following sections: In Section 2, we introduce and describe the case studies and methodology used to calculate the allocation factors used in the analysis; in Section 3, we present the results of the allocation factors for electricity and heat from the three different geothermal CHP plants; in Section 4, a final discussion of the results and concluding remarks are presented.

\section{Materials and Methods}

\subsection{Case Studies Description}

The case studies considered in this study were three existing geothermal CHP power plants, i.e., Chiusdino, Altheim, and Hellisheidi. General information regarding the power plants is reported in Table 1. The efficiency of a CHP plant is calculated as follows: gross electricity or heat produced/energy input. In a geothermal power plant, the energy input is defined as the total mass of fluid $(\mathrm{kg} / \mathrm{s})$ multiplied by the average enthalpy of inlet fluid $(\mathrm{kJ} / \mathrm{kg})[15]$.

Chiusdino is a power plant with a $20 \mathrm{MW}_{\mathrm{el}}$ nominal capacity located in Italy, in the municipality of Chiusdino, within the Larderello geothermal field [16]. A district heating unit, designed to provide heat to a neighboring town by exploiting the excess available geothermal heat, was recently initiated. When completed, the district heating will provide a $6744 \mathrm{~kW}_{\text {th }}$ nominal heating power, serving the central part of the town and some surrounding areas by hot water (a loop with delivery $\left(T_{D}\right)$ and return $\left(T_{R}\right)$ temperatures of 90 and $65^{\circ} \mathrm{C}$, respectively).

The Altheim power plant $[17,18]$ uses low-enthalpy geothermal water in the Austrian part of the Molasse Basin. The hot water flow is divided into two parts. After passing through a plate-type heat exchanger and depending on ambient temperature, approximately $11 \mathrm{MW}_{\text {th }}$ at $90^{\circ} \mathrm{C}$ in secondary closed-loop flows are used for heating public and residential buildings. The remainder of the hot water flow is directed to an organic Rankine cycle (ORC) turbine and power generator with a capacity of $1 \mathrm{MW}_{\mathrm{el}}$. The organic fluid employed in the power cycle is R134a [17,18]. The brine loop includes a submersible pump with an electrical power of $350 \mathrm{~kW}$ installed at $290 \mathrm{~m}$ [19]. Reinjection pressure at the wellhead was found to be 16 bars at a temperature of $65^{\circ} \mathrm{C}$.

The Altheim power plant combines the advantages of both parallel and serial CHP configurations. While the parallel configuration offers high temperature levels for the district heating system, the serial configuration allows high utilization of the heat source. 
Table 1. Characteristics of the geothermal combined heat and power (CHP) case study power plants.

\begin{tabular}{|c|c|c|c|c|}
\hline Location & & Chiusdino & Altheim & Hellisheidi \\
\hline Geothermal source type & & Liquid/Vapor & Liquid/Vapor & Liquid/Vapor \\
\hline Energy generation technology & & Flash & Binary/ORC & Double Flash \\
\hline \multirow{3}{*}{ Final energy use } & & $\mathrm{CHP}$ & $\mathrm{CHP}$ & $\mathrm{CHP}$ \\
\hline & & Electricity-oriented CHP & Heat-oriented CHP & Electricity-oriented CHP \\
\hline & & Medium scale & Small scale & Large scale \\
\hline Production scheme & & Serial & Serial/Parallel & Serial/Parallel \\
\hline \multicolumn{5}{|l|}{ Installed capacity } \\
\hline Thermal & $\mathrm{MW}_{\text {th }}$ & 6.744 & 11 & 133 \\
\hline Electric & $\mathrm{MW}_{\mathrm{el}}$ & 20 & 1 & 303.3 \\
\hline \multicolumn{5}{|l|}{ Geothermal fluid } \\
\hline Geothermal flow rate & $\mathrm{t} / \mathrm{h}$ & 130 & 278 & 1050 \\
\hline Temperature & ${ }^{\circ} \mathrm{C}$ & 196 & 106 & 180 \\
\hline Pressure & bar & 14.5 & 7.5 & 10 \\
\hline Specific enthalpy & $\mathrm{kJ} / \mathrm{kg}$ & 834 & 444 & 1365 \\
\hline \multicolumn{5}{|l|}{ Energy efficiency } \\
\hline Thermal & - & 0.07 & 0.60 & 0.10 \\
\hline Electric & - & 0.20 & 0.05 & 0.23 \\
\hline \multicolumn{5}{|l|}{ Annual energy production } \\
\hline Thermal & MWh & 13,094 & 32,168 & 520,475 \\
\hline Electric & MWh & 145,152 & 4852 & $2,219,049$ \\
\hline \multicolumn{5}{|l|}{ District heating temperatures } \\
\hline $\mathrm{T}_{\mathrm{D}}$ & ${ }^{\circ} \mathrm{C}$ & 90 & 90 & 90 \\
\hline $\mathrm{T}_{\mathrm{R}}$ & ${ }^{\circ} \mathrm{C}$ & 65 & 60 & 40 \\
\hline $\mathrm{T}_{\mathrm{amb}}$ & ${ }^{\circ} \mathrm{C}$ & 15 & 10 & 5 \\
\hline
\end{tabular}

The Hellisheidi power plant is a double flash CHP plant with $303.3 \mathrm{MW}_{\mathrm{el}}$ nominal electric capacity and $133 \mathrm{MW}_{\text {th }}$ thermal capacity. It is located in the high-temperature geothermal area of southwest Iceland, around $30 \mathrm{~km}$ to Reykjavik. Electricity generation is realized using two pressure stages $(6 \times 45 \mathrm{MW}$ high pressure turbines and $1 \times 33.3 \mathrm{MW}$ low pressure turbine) $[20,21]$. This power plant is arranged as a hybrid scheme for CHP, with serial freshwater low temperature preheating from the high-pressure flash exhaust steam, and parallel feed from the low-pressure flash condensate stream to heat preheated water up to the temperature required by the district heating of around $90{ }^{\circ} \mathrm{C}$.

The amounts of electricity and heat produced by a CHP geothermal plant need to be quantified. For the purpose of this study, for the Chiusdino and Hellisheidi power plants, we assumed that the electricity production represented the annual electricity supplied to the national grid, estimated as $7500 \mathrm{~h}$ of power plant operation at maximal load and an average $4 \%$ of parasitic consumption. For the Altheim power plant, parasitic consumption of a borehole pump $(350 \mathrm{~kW})$ was considered.

Usable heat provided to the district heating systems varied in compliance with the duration curve of external temperature. Therefore, to evaluate the heat supplied to a district heating system by the geothermal CHP plant, an estimate of the winter heat load of the town was performed.

The heating degree-days $\left(H D D_{\text {heating }}\right)$ approach is considered to be an approximate parameter to determine the seasonal heat load. The $H D D_{\text {heating }}$ are determined by integrating the daily differences between the reference temperature $T_{r e f}\left(18.3^{\circ} \mathrm{C} / 65^{\circ} \mathrm{F}\right)$ and hourly outdoor temperature $T_{\text {out }, i}$. The outdoor temperature is derived from typical meteorological year (TMY) data [22,23] for the selected locations. The degree days are defined as:

$$
H D D_{\text {heating }}=\frac{1}{24} \sum_{i=1}^{n}\left(T_{\text {ref }}-T_{\text {out }, i}\right)
$$

where $n$ refers to seasonal heating days. 
On this basis, and considering hourly temperatures, the DH heat load $(Q)$ was estimated as proportional to the indoor and outdoor average daily temperature difference during the heating season, having set the indoor temperature at $20^{\circ} \mathrm{C}$. The nominal design load of the CHP was the coldest hour in the year for each location. The heating period equivalent to the considered climatic zones was also considered.

The heat load fraction (DH Load Factor ${ }_{i}$ ) is defined as the ratio between the daily representative indoor and outdoor average temperature difference and the maximum indoor and outdoor temperature difference (corresponding to the design heat load) and can be calculated as follows:

$$
\text { DH Load Factor } i=\frac{T_{\text {in }}-T_{\text {out }, i}}{T_{\text {in }}-T_{\text {out }, \text { max }}}
$$

where $T_{\text {in }}$ and $T_{\text {out,i }}$ are the indoor and outdoor temperatures, respectively; $T_{\text {out, } \max }$ are the outdoor temperatures corresponding to the design heat loads $\left(-6.2^{\circ} \mathrm{C},-12.1^{\circ} \mathrm{C}\right.$, and $-10.1^{\circ} \mathrm{C}$ for Chiusdino, Altheim, and Reykjavík, respectively). The average monthly climatic data and DH load factors are reported in Figure 1.
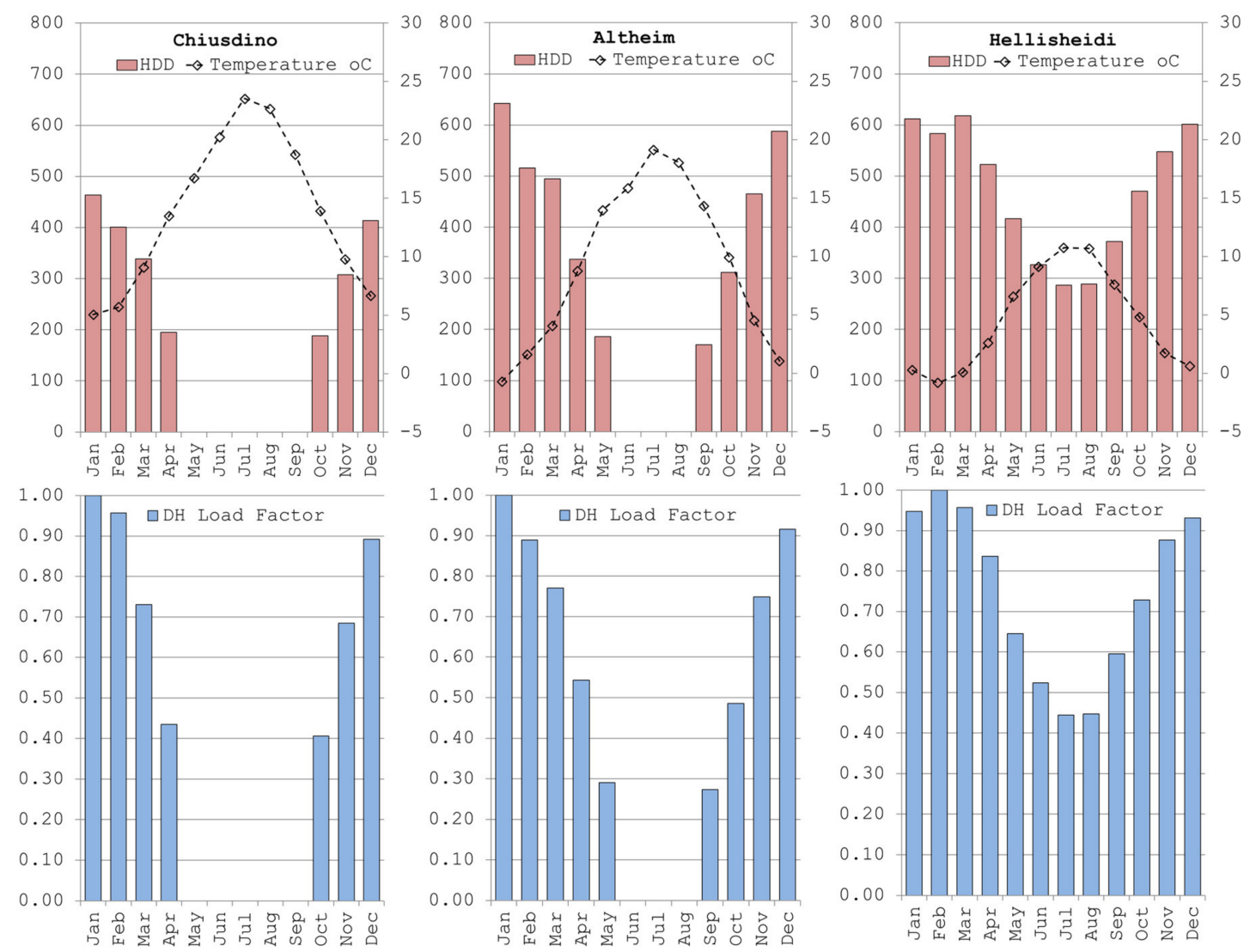

Figure 1. Average monthly external temperature, heating degree days (HDD), and district heating winter seasonal district heating $(\mathrm{DH})$ load factor for the municipalities of Chiusdino, Altheim, and Reykjavik.

Referring to these data and to the assumptions outlined, the overall expected annual heating load factors were evaluated to be about 44,45 , and $78 \%$, roughly corresponding to 3341, 3392, and 6797 operating hours/year for Chiusdino, Altheim, and Hellisheidi power plants, respectively. The obtained values are in line with site-specific data $[16,18,20]$.

\subsection{Exergy Allocation}

Exergy represents the maximum useful work that could be obtained from a system as it is brought to the specified reference environment from system state and it is the commonly accepted measure of quality or usefulness of the various energy forms and 
material streams flowing through a system and exiting as products and wastes [24,25]. Typically, the reference environment is specified in terms of temperature, pressure, and chemical composition. In other words, exergy measures the value of the various forms of energy associated with a material system at given conditions, expressed by its temperature, pressure, and chemical composition, which depends on the maximum work achievable from the system. On the one hand, from the definition of exergy, mechanical and electrical energies are equivalent to exergy because they can be integrally converted into work. On the other hand, heat is not pure exergy as the second principle of thermodynamics states that heat cannot be completely converted into work. Indeed, exergy of heat increases with an increase in temperature, because the maximum achievable work from a heat source increases with an increase in temperature. If temperature were infinite, the related heat would be pure exergy. The exergy of material streams, considering their mass flow rate, allows evaluating thermodynamic systems converting heat into electricity, heat, and cold as output products. In the case of chemicals as secondary output products of the system, the use of chemical exergy is recommended [26,27]. For a material stream, physical exergy flow $[\mathrm{MW}]$ is defined as follows:

$$
E x=\dot{m} \bullet\left[\left(h-h_{o}\right)-T_{o}(s-s)\right]
$$

where $h$ is specific enthalpy and $s$ is specific entropy at the system state conditions, $h_{0}$ and $s_{o}$ refer to the reference conditions (usually $p_{o}=101.325 \mathrm{kPa}$ and $T_{o}=298.16 \mathrm{~K}$ ), and $\dot{m}$ is the mass flow rate.

For the common situation where electricity and heat are produced (a CHP system), exergy is a useful approach for evaluating the output of the multigeneration system. As for shaft work, the exergy associated with electricity $\left(E x_{e l}\right)$ is equivalent to work energy $\left(E_{e l}\right)$ as:

$$
E x_{e l}=E_{e l}
$$

Exergy of heat $(Q)$ supplied by thermal energy reservoirs is equivalent to the work output of a Carnot heat engine operating between the reservoir (here, the heat source temperature driving force is the medium temperature of the geothermal resource) and the environment (here, the reference environment temperature is the annual external temperature in selected locations, i.e., 15,10 , and $5{ }^{\circ} \mathrm{C}$ for Chiusdino, Altheim, and Reykjavík, respectively). Here, heat exergy is identified as $E x_{Q}$ and can be expressed as follows:

$$
E x_{Q}=\theta \bullet Q
$$

where $\theta$ (Carnot factor or exergetic temperature accounting for the value of heat) is expressed as:

$$
\theta=\left(1-\frac{T_{0}}{T_{Q}}\right)
$$

and $T_{Q}$ and $T_{o}$ denote thermal product and reference environment temperatures, respectively. $T_{Q}$ is the entropy-average temperature of the heat produced by the CHP unit, calculated as:

$$
T_{Q}=\frac{Q}{(\Delta S)}
$$

where $\Delta S$ is the overall entropy variation of the heat interaction (from delivery to return in the case of a district heating system). The preceding equation can be applied for systems distributing either steam (with condensate recovery) or water, or other heat transfer fluids. In the specific case of distributing a single-phase heat transfer fluid, $T_{Q}$ can be evaluated as a log-mean temperature as follows:

$$
T_{Q}=\frac{T_{D}-T_{R}}{\log \left(\frac{T_{D}}{T_{R}}\right)}
$$


where $T_{D}$ is the delivery temperature and $T_{R}$ is the return temperature referring to the district heating system (primary circuit at plant gate).

The multiproduct issue about geothermal plants, seen as a whole with no details about internal subprocesses, is well addressed using exergy. In principle, the LCI, which involves creating an inventory of material and energy input and output flows for a product system, is also considered to be a whole. Moreover, the use of exergy is also recommended to solve allocation problems, which may arise depending on the parallel/serial arrangement with respect to the use of the resource. In principle, a LCA recommends that allocation should be avoided when a component serves one specific product.

\subsection{Primary Energy Savings Allocation}

Primary energy savings (PESs) is a measure used to evaluate the thermodynamic benefits during the operation time in the use phase (i.e., year), related to a CHP conversion system that produces fixed amounts of electricity and heat by recovering at least part of the heat necessary released to the environment as compared with two different systems separately producing the two amounts of electricity and heat using two different primary energy sources. The PESs of a CHP unit as a whole is expressed as follows [28]:

$$
P E S=P E_{R e f H}+P E_{R e f E}-P E_{C H P}
$$

where $P E_{C H P}$ is the primary energy used in the cogeneration unit for producing electricity and heat, $P E_{R e f H}$ is the primary energy used in the reference system used for the separate production of heat, and $P E_{R e f E}$ is the primary energy used in the reference system used for the separate production of electricity. The primary energy for electricity or heat from non-combustible renewables (hydro, wind, solar, and geothermal) is accounted for by using the "zero equivalent method." The zero equivalent method uses an equivalence of $0 \%$ between primary energy and electricity for all non-combustible renewable energy sources, i.e., $1 \mathrm{MJ}$ of electricity produced in a geothermal plant equals $0 \mathrm{MJ}$ of primary energy from a geothermal source [29]. The overall primary energy savings, PES, can be used later to obtain the allocated share of electricity and heat produced by the CHP unit.

Figure 2 presents a general concept of the PESs giving an idea of the achievable savings of a cogeneration system in terms of primary energy. A generic CHP system transforms 100 units of primary energy into 41 units of electricity and 44 units of heat. The remaining part of the primary energy is unavoidably lost into the environment. If the same amount of electricity and heat were produced separately in a conventional power plant and a boiler, the primary energy consumption would be higher $(46+125=171$ primary energy units), mainly because of the quite low conversion efficiency, and thus higher primary energy consumption for separate electricity production. The PESs due to the cogeneration unit as a whole is $171-100=70$ units.

\section{CHP production}

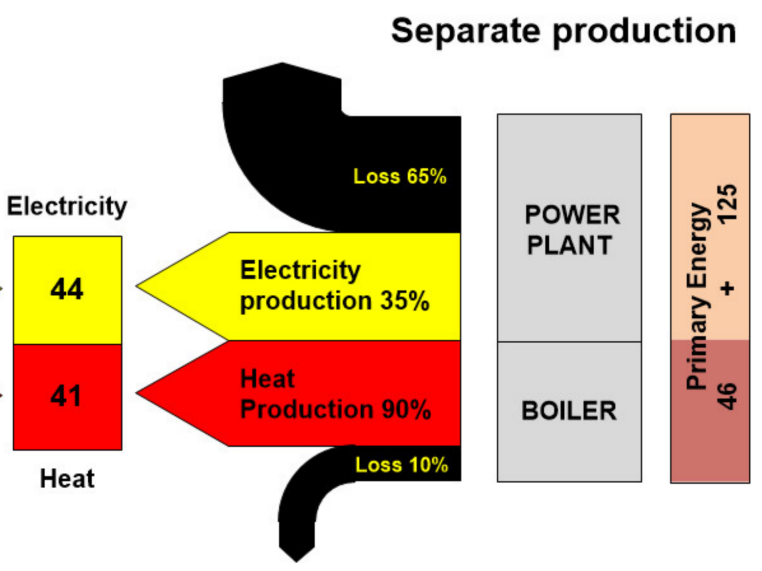

Figure 2. Primary energy savings. CHP vs. separate production. 
The PES accounts for the overall primary energy saving in a combined electricity and heat production as compared with separated production, generally non-renewable based and can also be presented as a ratio as follows:

$$
P E S=\left(\frac{P E_{R e f H}+P E_{R e f E}-P E_{C H P}}{P E_{\text {Ref } H}+P E_{\text {Ref } E}}\right) \bullet 100 \%
$$

Equation (10) leads to the expression of PES defined in Directive 2004/8/EC of the European Parliament [30] as:

$$
P E S=\left(1-\frac{1}{\frac{\eta_{C H P H}}{\eta_{\text {Ref } H}}+\frac{\eta_{C H P E}}{\eta_{\text {Ref } E}}}\right) \bullet 100 \%
$$

where $\eta_{C H P}$ is the heat efficiency of the cogeneration production defined as the annual useful heat output divided by the fuel input used to produce the sum of useful heat output and electricity from cogeneration, $\eta_{R e f H}$ is the reference efficiency at a national level for separate heat production, $\eta_{C H P}$ is the electrical efficiency of the cogeneration production defined as the annual electricity from cogeneration divided by the fuel input used to produce the sum of useful heat output and electricity from cogeneration, and $\eta_{R e f E}$ is the reference efficiency at a national level for separate production of electricity.

The PES can be remarkably effective for assessing systems with coproduction of electricity and heat, even though it is country dependent (through $\eta_{\operatorname{RefH}}$ and $\eta_{\operatorname{Ref} E}$, which primarily depend upon the reference fuel for separate heat and electricity production) and possibly variable in time. Moreover, $P E S$ is selected as an allocation method within the PCR UN CPC 171 and 173, Electricity, Steam and Hot/Cold Water Generation and Distribution, Version 4.0 of the International EPD ${ }^{\circledR}$ System [31]. Within Annex B of EN 15316-4-5:2017 [32], a template to specify the reference efficiency is provided, as well as informative default values ( $\eta_{\operatorname{Ref} E}=0.4, \eta_{\operatorname{RefH}}=0.9$ for all types of fuels). In Table 2, values of $\eta_{\operatorname{Ref} E}$ and $\eta_{R e f H}$ for some European countries, as well as the average for EU28, calculated in agreement with complete energy balances published periodically by EUROSTAT [33], are reported.

Table 2. Country related electricity and heat production and values of the reference efficiency at a national level for separate production of electricity $\left(\eta_{\text {Ref } E}\right)$ and the reference efficiency at a national level for separate heat production $\left(\eta_{\text {Ref } H}\right)$, for 2017 [33].

\begin{tabular}{ccccccc}
\hline & Separate Electricity & CHP Electricity & Separate Heat & CHP Heat & $\eta_{\text {RefE }}$ & $\eta_{\text {RefE }}$ \\
\hline Geographical Reference & GWh & GWh & GWh & GWh & - & - \\
\hline Italy & 184,138 & 91,392 & 3759 & 42,155 & 0.49 & 0.90 \\
France & 530,072 & 11,252 & 17,542 & 21,166 & 0.35 & 0.90 \\
Germany & 503,234 & 93,140 & 35,267 & 93,152 & 0.42 & 0.88 \\
Iceland & 14,628 & 4611 & 6196 & 2475 & 0.44 & 0.89 \\
Turkey & 273,506 & 3488 & - & 6254 & 0.48 & - \\
Average EU28 & $2,495,661$ & 501,187 & 168,831 & 403,256 & 0.40 & 0.89 \\
Average EU28 + Iceland + Turkey & $2,783,794$ & 509,286 & 175,028 & 411,986 & 0.41 & 0.89 \\
Annex B of EN & 184,138 & 91,392 & 3759 & 42,155 & 0.40 & 0.90 \\
15316-4-5:2017 & & & & & &
\end{tabular}

The average EU28 values of reference efficiencies for separate heat and power production are very close to those suggested in Annex B of EN 15316-4-5:2017. To gain generality and harmonization across different countries, these average values for efficiency reference are later proposed for calculations. 


\section{Results}

According to the technical parameters of the case study power plants and by applying the definitions of exergy and PES reported in Section 2, the exergies and PESs related to electricity and heat generated by a geothermal CHP were calculated, as well as their sums which represent the total produced output. The results are presented in Table 3. Figure 3 compares allocation factors obtained from the different allocation schemes for heat and electricity produced by the three geothermal power plants.

Table 3. Annual exergy and primary energy saving for national (N), European (EU) and natural gas (NG) efficiencies for three geothermal CHP power plants.

\begin{tabular}{ccccc}
\hline Power Plant & & Chiusdino & Altheim & Hellisheidi \\
\hline Carnot factor, $\theta$ & - & 0.178 & 0.186 & 0.176 \\
Exergy, heat, $E x_{Q}$ & MWh/y & 2329 & 4780 & 122,904 \\
Exergy, electricity $E x_{E L}$ & MWh/y & 145,152 & 4852 & $2,219,050$ \\
Exergy, total $E x_{\text {tot }}$ & MWh/y & 147,481 & 9632 & $2,341,953$ \\
\hline PES, heat (N) & MWh/y & 12,468 & 28,844 & 784,926 \\
PES, electricity (N) & MWh/y & 296,229 & 11,028 & $5,043,294$ \\
PES, total (N) & MWh/y & 308,696 & 39,871 & $5,828,220$ \\
\hline PES, heat (EU) & MWh/y & 12,608 & 28,844 & 784,926 \\
PES, electricity (EU) & MWh/y & 354,029 & 11,835 & $5,412,316$ \\
PES, total (EU) & MWh/y & 366,637 & 40,678 & $6,197,242$ \\
\hline PES, heat (NG) & MWh/y & 12,468 & 28,523 & 776,204 \\
PES, electricity (NG) & MWh/y & 273,872 & 9155 & $4,186,886$ \\
PES, total (N) & MWh/y & 286,339 & 37,678 & $4,963,090$ \\
\hline
\end{tabular}
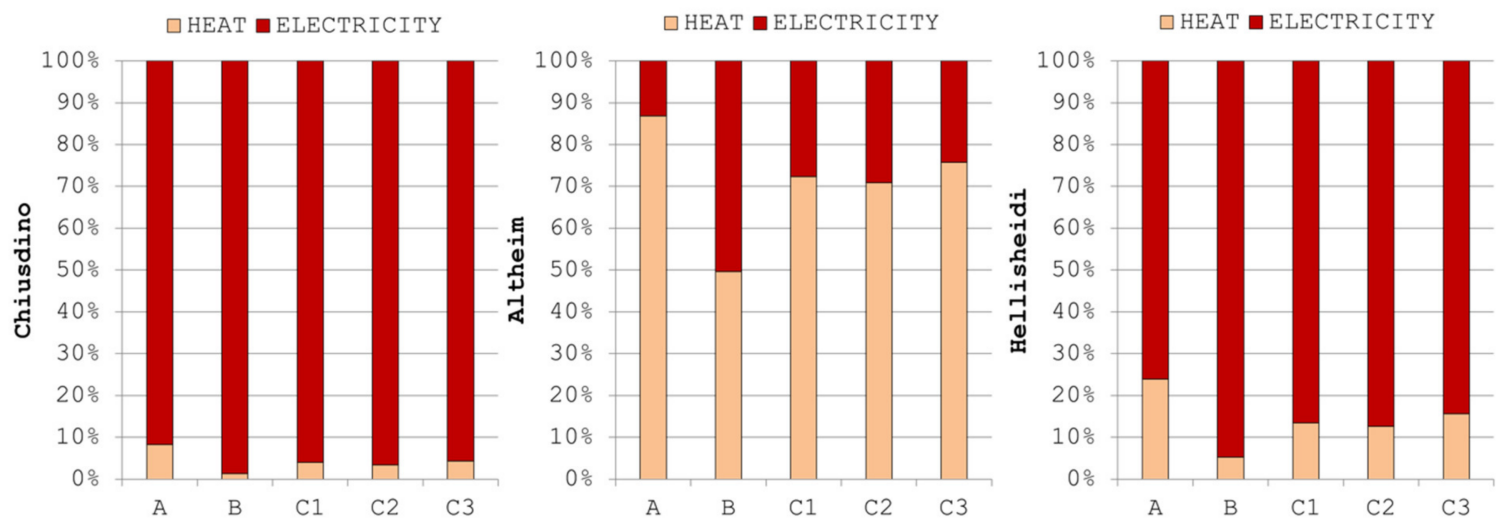

Figure 3. Allocation factors for heat and electricity produced by the Chiusdino, Altheim, and Hellisheidi power plants A, energy allocation; B, exergy allocation; C1, PES average national allocation; C2, PES average EU28 allocation; C3, PES natural gas allocation.

Generally, it can be observed that considering the low exergy value of the delivered heat due to the low temperature (typical of district heating), the contribution of heat in the total exergy output is significantly small. In addition, considering the limited operation of DH at full load, exergy characterizes the geothermal power station mainly as an electricity station. This is especially observed for the Chiusdino and Hellisheidi power plants, where the heat produced is below $10 \%$ ( 1.4 and $5.2 \%$, respectively) of the total exergy output, despite being nominally sized for about $7 \mathrm{MW}_{\text {th }}$ vs. $20 \mathrm{MW}_{\mathrm{el}}$, and $133 \mathrm{MW}_{\text {th }}$ vs. $303 \mathrm{MW}_{\mathrm{el}}$, respectively, and producing a relevant amount of district heating $(8 \%$ Chiusdino and $24 \%$ Hellisheidi).

In such cases, the PES allows a more effective evaluation of the direct use of heat with respect to exergy. Figure 3 shows that the share of heat of the PES $\left(P E S\right.$,heat $\left.=E_{Q} / \eta_{\operatorname{RefH}}\right)$ is much reduced with respect to the energy share (from 87 to $71-76 \%$ for Altheim, from 8 to 
$3-4 \%$ for Chiusdino, and from 24 to $13-16 \%$ for Hellisheidi, depending on the national or EU reference values adopted). In most countries, renewables are a valuable substitute of fossil fuels to produce heat from CHP district heating networks. In these specific cases, the use of PES allows a better valorization of heat.

A parametric study was performed to investigate how the exergy and the PES allocation factors change considering electricity- or heat-oriented CHP production, and to generalize the results. To this aim, the contribution of heat production was varied between 10 and $90 \%$ of the total, and the obtained allocation factors were compared in absolute terms and as a difference between energy shares (red line) and exergy, as well as the PES allocation factors for heat ( $\Delta$ heat share, heat allocation factor). In Figure 4 , the results of the parametric investigation are summarized.
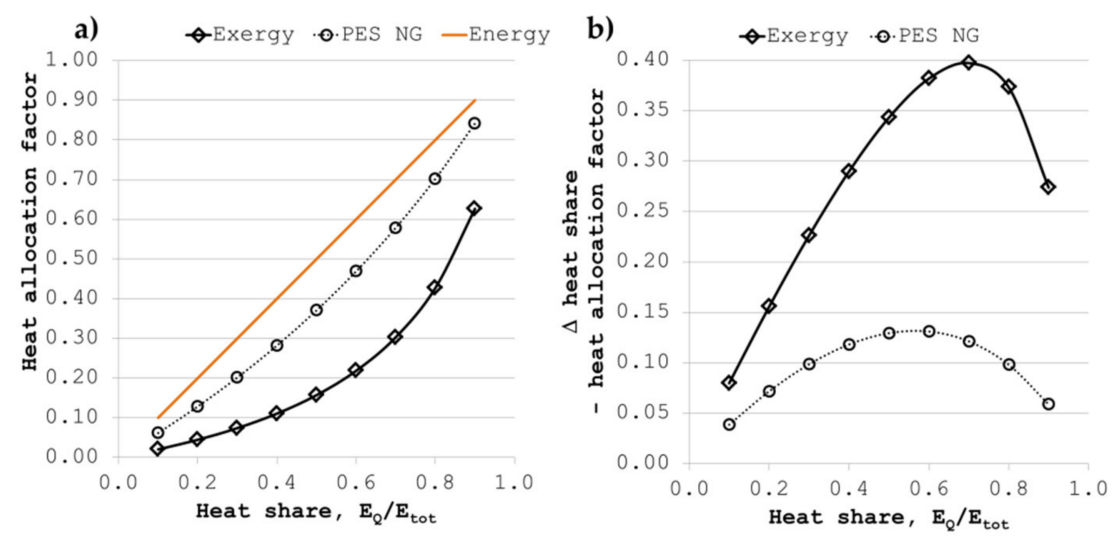

Figure 4. Allocation factors for useful heat as a function of heat contribution in CHP production. (a) Absolute values; (b) differences between heat share (energy allocation).

In Figure $4 a, b$, it can be observed that, in the whole range considered here, the exergy allocation factors are significantly lower (from 8 to $38 \%$ ) with respect to the share of heat produced. Considering the PES allocation rule, heat impact is still underestimated (from 4 to $14 \%$, depending on the heat production share) with respect to simple energy allocation. The PES allocation factor depends only on efficiency factors of separate heat production which can vary according to national conditions but is not affected by either external parameters (i.e., the reference temperature) or by the temperature level at which heat is produced, as for the exergy method.

Furthermore, by analyzing the difference between the heat share and allocation factors (Figure $4 \mathrm{~b}$ ), it should be noted that the difference increases with an increase in the heat share of the total production achieving its maximum value of 60 and $70 \%$ of heat contribution, for the PES and exergy methodologies, respectively. In particular, for the exergy method, the reduction in the maximum point is around $40 \%$, which significantly marginalizes the thermal energy while it overestimates the electricity impact in the heat productionoriented system.

Moreover, using the exergy method when dealing with the final use of low temperature heat (comfort heating for dwellings), further underestimates the impact of heat. Therefore, especially when using the exergy allocation method, one should be aware of proper interpretation of the results. In this light, the PES method may represent a valuable base for the allocation scheme.

\section{Discussion and Conclusions}

In this study, we assess different methodologies used for allocating the impacts of electricity and heat in CHP units. Exergy is often recommended for a LCA to solve the allocation problems of components producing electricity or heat, as it is a thermodynamic variable representing the value of a heat (or energy) interaction in comparable terms with electric power. However, this approach presents some limitations for analyzing 
the final (direct) use of heat (e.g., district heating). When heat is available at relatively low temperatures, the exergy is low, thus its value does not represent the real economic and environmental value of energy. This may result, in some cases, in almost the total replacement of electricity for all the considered impact categories. Typically, due to often low valorization of low-grade heat or moderate seasonal utilization (as happens, for example, when serving district heating), allocation methods using exergy or, even worse, power, marginalize the value of a fundamental service in CHP units, often more important than power. In this way, the fundamental benefit to the local community for using the combined produced heat, which otherwise should be in most cases provided with fossil fuels, is marginalized.

The PES approach to a CHP system, with specific reference to geothermal energy systems, allows a generalized comparison among quite different regional contexts. The PES is a more correct meter of comparison for CHP systems (ranging from 100\% electricity to 100\% heat) when it is adopted to evaluate the benefits of the direct use of heat. Moreover, it is an accepted indicator for systems producing heat and power (EU Directive 2004/8/EC [30]).

The PES method enables a more effective evaluation of the direct use of heat with respect to exergy because it does not penalize the heat due to its low temperature level, as exergy does. The use of the PES to allocate the impacts between useful products may suitably valorize the heat production in CHP systems. The PES has been used to compare different power plants, also including those electricity-oriented CHP systems, even though, for the latter, the significance of the PES for magnifying the value of heat produced is clearly lost. In this case, the use of the PES may also correctly allow a reasonable valorization of the heat for the functional units in CHP systems against powerplants producing electricity only.

In addition to the non-dimensional PES, it is also possible to calculate the overall PES $(\mathrm{MWh} / \mathrm{y})$, that is, the amount of primary energy saved (at a national level or in a specific project) by the energy-efficient use of combined heat and power.

Allocation based on the PES method is far more suitable than exergy and energy and is recommended for geothermal CHP plants. Although the method has been demonstrated for geothermal CHP plants, it can also be extended to any energy plant producing more than one useful energy flow.

Author Contributions: Conceptualization, D.F. and G.M.; methodology, D.F., G.M., and B.M.; software, B.M.; validation, M.L.P. and L.T.; formal analysis, M.L.P. and L.T.; investigation, D.F. and B.M.; resources, D.F. and M.L.P.; data curation, M.L.P., L.T., and B.M.; writing—original draft preparation, D.F, B.M., G.M., and M.L.P.; writing-review and editing, B.M., M.L.P., and L.T.; visualization, B.M.; supervision, D.F., G.M., and M.L.P.; project administration, D.F.; funding acquisition, D.F., M.L.P., and G.M. All authors have read and agreed to the published version of the manuscript.

Funding: This research was funded by the GEOENVI Project, European Union's Horizon 2020 Framework Program, grant number 818242.

Institutional Review Board Statement: Not applicable.

Informed Consent Statement: Not applicable.

Data Availability Statement: Raw data used to calculate country related electricity and heat production and values of the reference efficiency at a national level for separate production of electricity and heat are available online [33].

Acknowledgments: All authors acknowledge the European Union's Horizon 2020 Framework Program for funding Research and Innovation under grant agreement no. 818242 (GEOENVI) for funding. M.L. Parisi acknowledges the MIUR Grant, Department of Excellence 2018-2022.

Conflicts of Interest: The authors declare no conflict of interest. 


\section{References}

1. IEA. Understanding and Using the Energy Balance-Analysis. Available online: https://www.iea.org/commentaries/understandingand-using-the-energy-balance (accessed on 4 December 2020).

2. European Commission. Clean Energy for all Europeans Package. Energy. Available online: https://ec.europa.eu/energy/topics/ energy-strategy/clean-energy-all-europeans_en (accessed on 4 December 2020).

3. Turconi, R.; Boldrin, A.; Astrup, T. Life cycle assessment (LCA) of electricity generation technologies: Overview, comparability and limitations. Renew. Sustain. Energy Rev. 2013, 28, 555-565. [CrossRef]

4. Eberle, A.; Heath, G.; Nicholson, S.; Carpenter, A.; Eberle, A.; Heath, G.; Nicholson, S.; Carpenter, A. Systematic Review of Life Cycle Greenhouse Gas Emissions from Geothermal Electricity. National Renewable Energy Laboratory: Golden, CO, USA, 2017.

5. Tomasini-Montenegro, C.; Santoyo-castelazo, E.; Gujba, H.; Romero, R.J.; Santoyo, E. Life cycle assessment of geothermal power generation technologies: An updated review. Appl. Therm. Eng. 2017, 114, 1119-1136. [CrossRef]

6. Parisi, M.L.; Douziech, M.; Tosti, L.; Pérez-López, P.; Mendecka, B.; Ulgiati, S.; Fiaschi, D.; Manfrida, G.; Blanc, I. Definition of LCA guidelines in the geothermal sector to enhance result comparability. Energies 2020, 13, 1-18. [CrossRef]

7. DiPippo, R. Geothermal Power Plants: Principles, Applications, Case Studies and Environmental Impact, 4th ed.ButterworthHeinemann: Oxford, UK, 2015.

8. International Organization for Standardisation. ISO 1440 Environmental management-life cycle assessment-principles and framework. Lond. Br. Stand. Inst. 2006. [CrossRef]

9. Ekvall, T.; Finnveden, G. \{A\}llocation in \{ISO\} 14041-A critical review. J. Clean. Prod. 2001, 9, 197-208. [CrossRef]

10. Tereshchenko, T.; Nord, N. Uncertainty of the allocation factors of heat and electricity production of combined cycle power plant. Appl. Therm. Eng. 2015, 76, 410-422. [CrossRef]

11. Karlsdottir, M.R.; Heinonen, J.; Palsson, H.; Palsson, O.P. High-Temperature Geothermal Utilization in the Context of European Energy Policy-Implications and Limitations. Energies 2020, 13, 3187. [CrossRef]

12. Blanc, I.; Damen, L.; Douziech, M.; Fiaschi, D.; Manfrida, G.; Parisi, M.L.; Lopez, P.P.; Ravier, G.; Tosti, L.; Mendecka, B. First Version of Harmonized Guidelines to Perform Environmental Assessment for Geothermal Systems Based on LCA and non LCA Impact Indicators: LCA Guidlines for Geothermal Installations. Deliverable 3.2, GEOENVI Project. 2020. Available online: https:/ / www.geoenvi.eu/wp-content/ (accessed on 4 December 2020).

13. Frick, S.; Kaltschmitt, M.; Schröder, G. Life cycle assessment of geothermal binary power plants using enhanced low-temperature reservoirs. Energy 2010, 35. [CrossRef]

14. Martín-gamboa, M.; Iribarren, D.; Dufour, J. Geothermics On the environmental suitability of high- and low-enthalpy geothermal systems. Geothermics 2015, 53, 27-37. [CrossRef]

15. Zarrouk, S.J.; Moon, H.; Zarrouk, S.J. Efficiency of geothermal power plants: A worldwide review. Geothermics 2014, 51, 142-153. [CrossRef]

16. Basosi, R.; Bonciani, R.; Frosali, D.; Manfrida, G.; Parisi, M.L.; Sansone, F. Life Cycle Analysis of a Geothermal Power Plant: Comparison of the Environmental Performance with Other Renewable Energy Systems. Sustainability 2020, 12, 2786. [CrossRef]

17. Pernecker, G.; Ruhland, J. Altheim Geothermal Plant for Electricity Production By Organic Rankine Cycle Turbogenerator. Twenty-First Work. Geotherm. Reserv. Eng. 1996, 151, 73-77.

18. Pernecker, G.; Uhlig, S. Low enthalpy power generation with ORC-Turbogenerator The Altheim Project, Upper Austria. Geo Heat Center Bull. 2002, 1, 26-30.

19. Goldbrunner, J. State, Possible Future Developments in and Barriers to the Exploration and Exploitation of Geothermal Energy in Austria-Country Update. In Proceedings of the World Geothermal Congress 2005, Antalya, Turkey, 24-29 April 2005; pp. 1-11.

20. Karlsdottir, M.R.; Heinonen, J.; Palsson, H.; Palsson, O.P. Life cycle assessment of a geothermal combined heat and power plant based on high temperature utilization. Geothermics 2020, 84, 101727. [CrossRef]

21. Colucci, V.; Manfrida, G.; Mendecka, B.; Talluri, L.; Zuffi, C. LCA and Exergo-Environmental Evaluation of a Combined Heat and Power Double-Flash Geothermal Power Plant. Sustainability 2021. [CrossRef]

22. METEONORM Version 6.1-Edition 2009. Global Meteorological Database for Engineers, Planners and EducationVersion 6.1-Edition 2009 Software and Data on CD-ROM. Available online: http:/ /www.antherm.eu/meteonorm/mn6_prodinfo.pdf (accessed on 4 December 2020).

23. Comitato Termotecnico Italiano (CTI). Anni Tipo Climatici per Applicazioni Termotecniche-Regione Toscana. Available online: https:/ / try.cti2000.it/ (accessed on 3 April 2021).

24. Szargut, J. Exergy Method: Technical and Ecological Applications; WIT Press: Southampton, UK, 2005.

25. Szargut, J.; Zibik, A.; Stanek, W. Depletion of the non-renewable natural exergy resources as a measure of the ecological cost. Energy Convers. Manag. 2002, 43, 1149-1163. [CrossRef]

26. Morris, D.R.; Szargut, J. Standard chemical exergy of some elements and compounds on the planet earth. Energy 1986, I, 733-755. [CrossRef]

27. Kotas, T.J. The Exergy Method of Thermal Plant Analysis; Elsevier: Amsterdam, The Netherlands, 1985; ISBN 0894649418.

28. Frangopoulos, C.A. A method to determine the power to heat ratio, the cogenerated electricity and the primary energy savings of cogeneration systems after the European Directive. Energy 2012, 45, 52-61. [CrossRef]

29. Stoffregen, A.; Schuller, O. Primary Energy Demand of Renewable Energy Carriers-Part 1: Definitions, Accounting Methods and Their Application. Build. Serv. Eng. 2014, 2, 1-18. [CrossRef] 
30. EUR-Lex. European Parliament Directive 2004/8/EC of the European Parliament and of the Council of 11 February 2004. Available online: https:/ / eur-lex.europa.eu/legal-content/EN/ALL/?uri=celex\%3A32004L0008 (accessed on 3 April 2021).

31. EPD PRODUCT CATEGORY RULES (PCR): Electricity, Steam and Hot Water Generation and Distribution Product Category Classification: UN CPC 171, 173 Version 4.0. Available online: https:/ / portal.environdec.com/ (accessed on 26 May 2020).

32. EN 15316-4-5:2017 Energy Performance of Buildings. Method for Calculation of System Energy Requirements and System Efficiencies. District Heating and Cooling, Module M3-8-5, M4-8-5, M8-8-5, M11-8-5. Available online: https:/ / standards.iteh.ai/ catalog/standards/cen/68067f54-7f43-4f5d-b020-17449b7c3d6b/en-15316-4-5-2017 (accessed on 26 May 2020).

33. EUROSTAT. Complete Energy Balances-Annual Data [nrg_110a]. Available online: https://www.eea.europa.eu/data-andmaps/data/external/energy-statistics-gross-inland-energy (accessed on 26 May 2020). 